
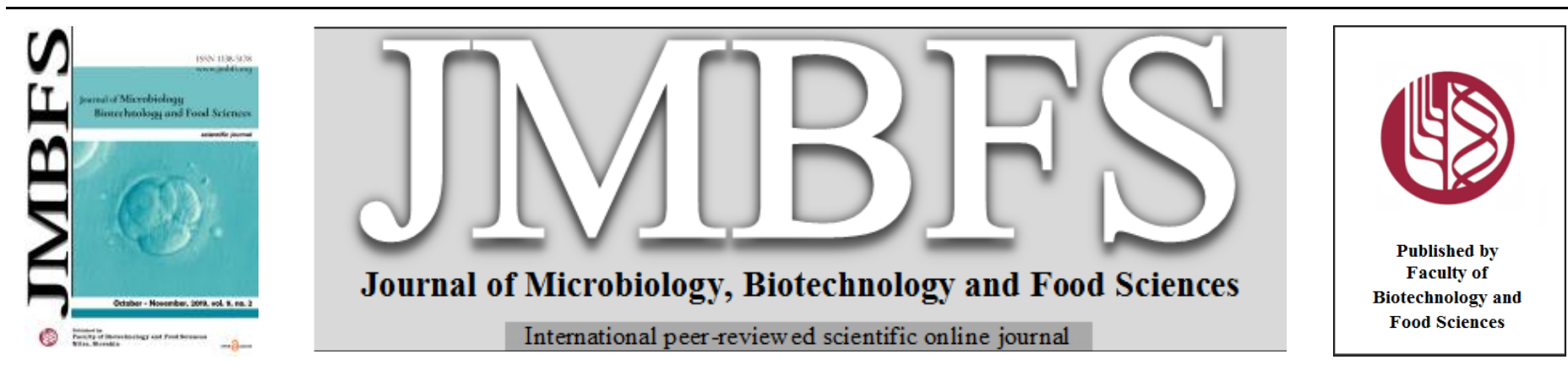

\title{
EFFECTS OF LOW SODIUM CHLORIDE SUBSTITUTES ON PHYSICO-CHEMICAL AND SENSORY PROPERTIES OF KAPI, A FERMENTED SHRIMP PASTE, DURING FERMENTATION
}

\author{
Jittrepotch Nitipong*, Rojsunthornkitti Kamonwan and Kongbangkerd Teeraporn
}

Address(es): Nitipong Jittrepotch corresponding author,

Department of Agro-Industry, Faculty of Agriculture Natural Resource and Environment, Naresuan University, Phitsanulok, Thailand,

Phone: (+66) 5596000 Ext. 2747.

*Corresponding author: nitipongj@nu.ac.th

doi: 10.15414/jmbfs.2020.9.4.695-699

\section{ARTICLE INFO}

Received 20.9. 2018

Revised 15. 3. 2018

Accepted 8. 4. 2019

Published 3. 2. 2020

Regular article

OPEN $\partial_{\text {ACCESS }}$

\section{ABSTRACT}

The effects of low sodium chloride substitutes on physico-chemical and sensory properties of Kapi, a fermented shrimp paste during fermentation period were investigated. Changes in sodium chloride content, thiobarbituric acid reactive substances (TBARS), antioxidant activities as determined by DPPH (1, 1-diphenyl-2-picryl hydrazine) and ABTS (2,2-axino-bis (3-ethylbenzothiazoline-6sulfonic acid) radical, water activity (Aw), color values, weight loss content and sensory evaluation were monitored. During fermentation, the Aw was decreased in all samples $(\mathrm{P} \leq 0.05)$. The samples using sodium chloride substitute contented lower sodium chloride than control $(100 \% \mathrm{NaCl})(\mathrm{P} \leq 0.05)$. We found that a replacement by $\mathrm{KCl}$ and $\mathrm{CaCl}_{2}$ decreased intensity of reactions to lipid oxidation, while $100 \% \mathrm{NaCl}$ had a significantly higher TBARS value than other samples ( $\mathrm{P} \leq 0.05)$. The percentage of inhibition DPPH and ABTS radical scavenging activity significant increased $(\mathrm{P} \leq 0.05)$ with increasing fermentation periods, but there was no significant difference between treatments. The result of sensory evaluation revealed that fermented shrimp paste with 25 and $50 \% \mathrm{KCl}$ had the highest overall acceptance scores with the $\mathrm{CaCl}_{2}$ replacement $(\mathrm{P} \leq 0.05)$, there was no significant difference from $100 \% \mathrm{NaCl}$.

Keywords: Kapi, sodium chloride substitutes, physico-chemical and sensory properties

\section{INTRODUCTION}

Salt is an inorganic compound. It's made when $\mathrm{Na}$ (sodium) and $\mathrm{Cl}$ (chloride) come together to form white, crystalline cubes. Salt imparts a number of functional properties in meat products, contributing to the water-holding capacity, color, fat binding properties and flavor.

Excessive salt consumption kills an estimated 2.5 million people worldwide WHO recommends consumption of less than 5 grams of salt per day in order to improve population health.Thais consume an average of 10.8 grams of salt per day (over 4,000 milligrams of sodium). This rate is more than double the recommended daily amount of salt. The main sources of salt derive from salt added during cooking, packaged food, and street food. High dietary sodium consumption is associated with high blood pressure (WHO, 2007; He and MacGregor, 2008) which is a major risk factor for cardiovascular disease (WHO, 2012).

Fermentation is a common practice in food preservation and it plays an importan role in improvement of nutritional and functional properties of foods (Steinkraus, 2002). Fermented food products are good source of peptides and amino acids (Rajapakse et al., 2005; Sathivel et al., 2003). During fermentation process, a specific amino acid is synthesized in large quantities. The selected microorganism is cultured with nitrogen and carbohydrate sources and during the process of fermentation L-form of the amino acid is produced. Fermented shrimp products are mainly categorized into sauces, pastes, and lacto-fermented products. Those products are known with diverse names by local population of each nation. While, most of the people in the countries in Southeast Asia region regularly use shrimp sauce and paste in their daily cooking, fermented shrimp products are only produced and consumed by the people of Malaysia, Thailand and the Philippines. Depending on the species of shrimp, the quantity of salt used, and the treatment of raw materials prior to fermentation, different types of products are produced (Mizutani $\boldsymbol{e t}$ al., 1992). In order to produce fermented shrimp products, salt is mixed with cleaned fresh or dried shrimp and allowed to be fermented for several months in order to enable the indigenous enzymes to auto-digest the meat and create products with high amino acids content. The enzymatic fermentation of shrimp mediated by indigenous proteases yields short chain peptides and free amino acids which render the typical flavour and taste.
Salt is added to prevent deterioration and food poisoning as well as to yield meaty-savoury flavour (Steinkraus, 2002).

Thai traditional fermented shrimp paste is commonly known as Kapi. It is widely used as a condiment in many Thai cuisines, in particular chili pastes, curry pastes and sauces. Kapi is traditionally prepared from shrimp or mysid shrimp mixed with salt at the ratio of 3-5:1 and then sun-dried to decrease the moisture content, and finally it is homogenized to obtain a homogenous product (paste). During ripening period, it is replaced and allowed to ferment for 2-6 months to develop desirable and unique flavors and aromas. The mixture is sun-dried and thoroughly ground before being compacted in a container usually earthen jar. Fermentation of Kapi is generally taken place until the typical aroma is developed and the fermentation time varies with each manufacturers (Phithakpol, 1993).

In Thailand, Kapi can be classified into two distinct types: Kapi Ta Dam (black paste) and Kapi Ta Deang (red paste) obtained from mangrove canals and seagrass beds, respectively. Only one species of mysid shrimp, Mesopodopsis orientalis, found in mangrove canals of the Andaman Sea is used solely for production of Kapi Ta Dam. In contrast, three different species of shrimps from the genus Acetes; Acetes indicus, Acetes japonicas, and Acetes crythraeus, found in seagrass beds in the Andaman Sea are used for production of Kapi Ta Deang (Pengchumrus and Upanoi 2005).

Due to the harmful effects and increasing consumption of sodium, health authorities are increasingly interested in reducing salt intake. Reducing salt levels in processed food has been one of the goals of the food industry (World Health Organization, 2011). Another way to reduce sodium is partially replaced by other salt. The most commonly used is potassium chloride $(\mathrm{KCl})$, which has similar properties to $\mathrm{NaCl}$ and is recognized as safe, can be used without loss of functionality (Thaisa et al., 2017). Potassium chloride provides one of the most direct substitutions due to the similarity in molecular composition, but its use can be limited due to negative sensory attributes (Askar et al., 1994). However, with respect to fermentation shrimp paste (Kapi), there has been very little research on the use of these salts on physico-chemical and sensory properties. Therefore, the objective of this research is aimed to elucidate the effects of low sodium chloride substitutes on physico-chemical and sensory properties of Kapi, a Thai fermented shrimp paste, during fermentation. 


\section{MATERIALS AND METHODS}

\section{Preparation of fermented shrimp paste (Kapi)}

Shrimp (Acetes vulgaris) were obtained from Samuth sakorn province, the Gulf of Thailand in June 2017 and placed in ice with an ice-to-shrimp ratio of 2:1 (w/w). Upon arrival, shrimp were divided into five groups. Each group was mixed with ground solar salt, using the following formulations: Formulation I $100 \% \mathrm{NaCl}$ salt, formulation II: $\mathrm{NaCl}$ and $\mathrm{KCl}$ at $50 \%$ each, formulation III $75 \%$ $\mathrm{NaCl}$ and $25 \% \mathrm{KCl}$, formulation IV $\mathrm{NaCl}$ and $\mathrm{CaCl}_{2}$ at $50 \%$ each an formulation $\mathrm{V} 75 \% \mathrm{NaCl}$ and $25 \% \mathrm{CaCl}_{2}$. The mixture was kept overnight in plastic woven basket. The extrudes were drained continuously through the basket in order to lower moisture content. The mixture was sun-dried for $6 \mathrm{hr}$. and then blended thoroughly with hammer mill and transferred into $3 \mathrm{~L}$ plastic container with the volume up to the brim. The paste was packed in the plastic box and the plastic box was then covered entirely with a polyethylene sheet. The samples were left for fermentation at room temperature $\left(30-35^{\circ} \mathrm{C}\right)$ for 3 months. Samples were taken every weeks of fermentation for analyses.

\section{Determination of $\mathrm{NaCl}$}

$\mathrm{NaCl}$ content in samples were measured by the method of AOAC (2002). Sample $(1 \mathrm{~g})$ was treated with $10 \mathrm{ml}$ of $0.1 \mathrm{~N} \mathrm{AgNO}_{3}$ and $10 \mathrm{ml}$ of $\mathrm{HNO}_{3}$. The mixture was boiled gently on hot plate until all solid except $\mathrm{AgCl}_{2}$ were dissolved (usually $10 \mathrm{~min}$ ). The mixture was then cooled using running water and $50 \mathrm{ml}$ distilled water and $5 \mathrm{ml}$ of ferric alum indicator were added. The mixture was titrated with standardized $0.1 \mathrm{~N} \mathrm{KSCN}$ until the solution became permanent brownish-red. The salt content was expressed as $\% \mathrm{NaCl}$.

\section{Determination of thiobarbituric acid reactive substances (TBARS)}

TBARS was determined according to the method of Buege and Aust (1978) Sample $(5 \mathrm{~g})$ was homogenized with $25 \mathrm{ml}$ of TBARS solution (TBA $(0.375$ $\mathrm{g} / 100 \mathrm{ml})$, TCA $(15 \mathrm{~g} / 100 \mathrm{ml})$, and $\mathrm{HCl} 0.25 \mathrm{~mol} / \mathrm{l})$. The mixture was heated for $10 \mathrm{~min}$ in boiling water $\left(95-100^{\circ} \mathrm{C}\right)$ to develop a pink color. Then the mixture was cooled with running water and centrifuge at $5500 \mathrm{~g}$ for $25 \mathrm{~min}$. The absorbance of the supernatant was measured at $532 \mathrm{~nm}$ using a spectrophotometer. TBARS value was calculated from a standard curve of malonaldehyde and express as mg malonaldehyde/kg sample.

\section{Measurement of antioxidant activity by ABTS assay}

Antioxidant activity was estimated using the ABTS assay following a modified method of Jeong et al. (2010). Briefly, $2.45 \mathrm{mM} \mathrm{K}_{2} \mathrm{~S}_{2} \mathrm{O}_{8}$ solution was added into $7 \mathrm{mM}$ ABTS $(1: 1, \mathrm{v} / \mathrm{v})$ and kept for $16-12 \mathrm{~h}$ at room temperature in the dark to make ABTS solution. The ABTS solution was diluted with ethanol to an absorbance of less than $0.700 \pm 0.02$ at $734 \mathrm{~nm}$ before analysis. The Kapi extracts were diluted with ethanol $(500,1,000,1,500,2,000$ and $2,500 \mathrm{mg} / \mathrm{L})$ and $1.0 \mathrm{~m}$ of the diluted sample was mixed with $2.9 \mathrm{ml}$ of the diluted ABTS solution. After $20 \mathrm{~min}$, the absorbance was measured at $734 \mathrm{~nm}$ using the spectrophotometer. The calculation of the percent inhibition of antioxidant activity was as follows.

$$
\% \text { inhibition }=\frac{(A c-A s) \times 100}{A c}
$$

Where Ac is the absorbance of control and As is the absorbance of sample.

\section{Measurement of antioxidant activity by DPPH assay}

Antioxidant activity was estimated using the DPPH (1, 1-diphenyl-2-picryl hydrazine) assay described previously (Wu et al., 2003) with some modification. The DPPH solution $0.15 \mathrm{mM}$ in $95 \%$ ethanol was prepared and $1.5 \mathrm{~mL}$ of this solution was added to $1.5 \mathrm{ml}$ of extract solution (water extract from salted shrimp pastes). The mixture was then mixed and allowed to stand for $30 \mathrm{~min}$ in the dark at room temperature. The absorbance was measured at $517 \mathrm{~nm}$ using the spectrophotometer. The blank was prepared in the same manner except the distilled water was used instead of the sample.

\section{Measurement of water activity (Aw)}

The Aw was determined at $25^{\circ} \mathrm{C}$ using Aw box (Novasina Awc 200, Switzerland).

Physical analyses

\section{Determination of weight loss}

Weight loss was determined as described by Nakao et al. (1991). Treated sample $(100 \mathrm{~g})$ was accurate weighed during fermentation using an analytical balance (Model B 3100P, Germany). Difference in weight of Kapi before and after fermentation was referred to as 'weight loss'.

\section{Color measurement}

Color was measured using a Hunter Lab colorimeter (DP 9000, Hunter Associates Laboratory, Reston, VA, USA) with the angle $10^{\circ}$ and a D65 illuminant standard observed. Color evaluation was made through the CIE L*, a*, $b^{*}$ system. CIE L*, a*, b* values were determined as indicators of lightness, redness/greenness, and yellowness/blueness, respectively.

\section{Acceptability test}

Sensory properties of Kapi were provided by Kapi producers. Kapi was evaluated for acceptance by an untrained 50-member panels. The panellists were undergraduate students in Department of Agro-Industry, Faculty of Agriculture, Natural Resource and Environment, Naresuan University of age ranged between 20-22 years. Panellists had sensorial acquaintance with Kapi. A nine-point hedonic scale, in which a score of $1=$ dislike extremely, $5=$ neither like nor dislike and $9=$ like extremely, was used for evaluation (Meilgarrd, Civille and Carr, 1990). A formulation for producing Thai shrimp paste chili sauce (Nam Prik Kapi) was developed in the laboratory. The ingredients used in preparing the shrimp paste chili were fermented shrimp paste, garlic, fresh red, palm sugar, lime juice and fish sauce. Samples were randomly selected and coded with threedigit random number and presented to the panellists at room temperature. During evaluation, the panelists were situated in private booths. Room temperature water was given to rinse the mouth between samples. The panellists evaluated each sample for color, flavor, taste, and overall likings.

\section{Statistical analysis}

Microsoft Excel 5.0 (Microsoft Co., Washington, USA) was used for all statistical analyses. Data were analyzed using one-way ANOVA, and means were compared using Duncan's multiple range test. Differences were considered to be significant at $\mathrm{P} \leq 0.05$.

\section{RESULTS AND DISCUSSION}

\section{Changes in $\mathrm{NaCl}$ contents}

Recent reports for the Department of Health in Thailand have shown that the average $\mathrm{NaCl}$ consumption among Thai people was $10.8 \mathrm{~g}$ per day per person. $\mathrm{NaCl}$ intake exceeds the nutritional recommendation in most industrialized countries becoming one concern for public health. Agreement with Pongsetkul $e$ al. (2014) reported salt content of salted shrimp paste produced in Thailand contained $22.77-35.47 \% \mathrm{NaCl}$. In the present study, the percentage of $\mathrm{NaCl}$ used in the modified products gave rise to significant reduction in sodium chloride content. Salt content of salted shrimp paste was in the range of $10.89 \pm 0.85$ and $22.89 \pm 1.05 \% \mathrm{NaCl}$. The percentage of reduction in relation to $10.80 \%, 32.25 \%$, $11.0 \%$ and $30.85 \%$ for II, III, IV and V, respectively (Figure 1). No significant difference $(\mathrm{P} \geq 0.05)$ was found in the salt contents in each formulation during fermentation period. Similarly, Jittrepotch et al. (2015) reported that no significant difference of $\mathrm{NaCl}$ content in Plaa -som, a Thai fermented fish product prepared by using low sodium chloride substitutes during fermentation time.

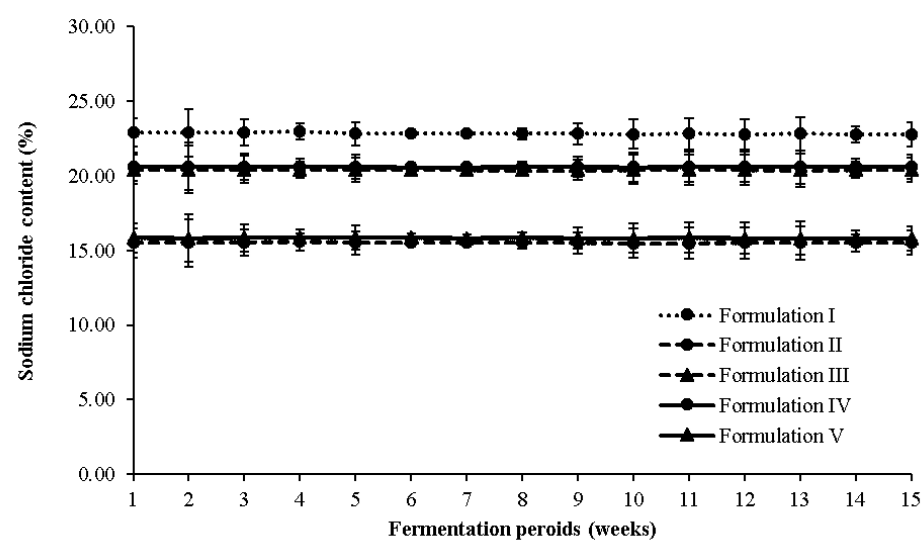

Figure 1 Changes in sodium chloride content of fermented shrimp paste with partial replacement of sodium chloride during fermentation period. Formulation I: $100 \% \mathrm{NaCl}$ salt, formulation II: $\mathrm{NaCl}$ and $\mathrm{KCl}$ at $50 \%$ each, formulation III $\mathrm{NaCl} 75 \%$ and $\mathrm{KCl}$ at $25 \%$, formulation IV $\mathrm{NaCl}$ and $\mathrm{CaCl}_{2}$ at $50 \%$ each and formulation $\mathrm{V} \mathrm{NaCl} 75 \%$ and $\mathrm{CaCl}_{2} 25 \%$

\section{Changes in Aw}

Changes in Aw of all samples during fermentation period are shown in Figure 2. No significant difference $(\mathrm{P} \geq 0.05)$ was found in $\mathrm{Aw}$ atthe beginning. Aw of al samples was between $0.68 \pm 0.01$ to $0.72 \pm 0.01$ At the final,Aw of all samples was 
between $0.66 \pm 0.01$ to $0.71 \pm 0.01$ ( $\mathrm{P} \leq 0.05$ ). Formulation II, $\mathrm{NaCl}$ and $\mathrm{KCl}$ at $50 \%$ each showed lower $\mathrm{Aw}$ in comparison with other groups $(\mathrm{P} \leq 0.05)$. Similar results were found by MoraGallego et al. (2016), in fermented sausages added with $\mathrm{KCl}$. The partial replacement of $\mathrm{NaCl}$ by $\mathrm{KCl}$ might influence $\mathrm{Aw}$ because potassium ion has higher polarity compared to sodium, which could enable it to bind to a greater number of water molecules, leading to a lower Aw. In addition, Pongsetkul et al. (2014) reported that the Aw of salted shrimp paste was in the range of $0.695-0.774$.

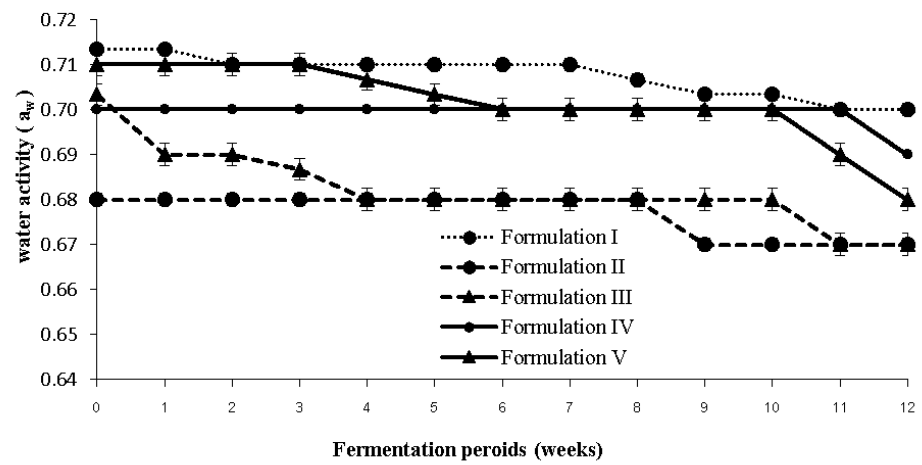

Figure 2 Changes in water activity of fermented shrimp paste with partial replacement of sodium chloride during fermentation period. Formulation I: $100 \%$ $\mathrm{NaCl}$ salt, formulation II: $\mathrm{NaCl}$ and $\mathrm{KCl}$ at $50 \%$ each, formulation III $\mathrm{NaCl} 75 \%$ and $\mathrm{KCl}$ at $25 \%$, formulation $\mathrm{IV} \mathrm{NaCl}$ and $\mathrm{CaCl}_{2}$ at $50 \%$ each and formulation $\mathrm{V}$ $\mathrm{NaCl} 75 \%$ and $\mathrm{CaCl}_{2} 25 \%$

\section{Change in TBARS}

Lipid oxidation is one of the main phenomena responsible for the reduced shelf life and sensory quality of fermented meat products. TBARS has been used to measure the concentration of relatively polar secondary reaction products, especially aldehydes (Nawar, 1996). Figure 3 shows the effect on lipid oxidation (TBARS) of reducing or replacing $\mathrm{NaCl}$ with $\mathrm{KCl}$ and/or $\mathrm{CaCl}_{2}$ during the fermentation period of shrimp paste. At the beginning of fermentation period (Day 0), the measured TBARS amounts were not significantly different among the treatments. On the $2^{\text {nd }}$ weeks of fermentation, only formulation I $(100 \%$ $\mathrm{NaCl})$ presented TBARS values higher than other groups $(P<0.05)$. At the end of the process (12 weeks), the treatments with $100 \% \mathrm{NaCl}$ (formulation I) showed significantly higher TBARS compared to the other groups. The data reported agree with previous measurements of TBARS in fermented fish products (Jittrepotch, et al., 2015). There are many postulations as how sodium chloride acts as a prooxidant. Kanner and Rosenthal (1992) argued that $\mathrm{NaCl}$ acts as a prooxidant by displacing the iron ions with sodium in the heme pigments of the muscle tissue, whereas others recognize the chloride ion acting upon the lipid as the source (Ellis et al., 1970). According to Rhee and Ziprin (2001), the addition of $0.5-2.5 \% \mathrm{NaCl}$ in meat products is enough to provide a prooxidant effect, thus increasing oxidative reactions during the processing and storage stages of products.

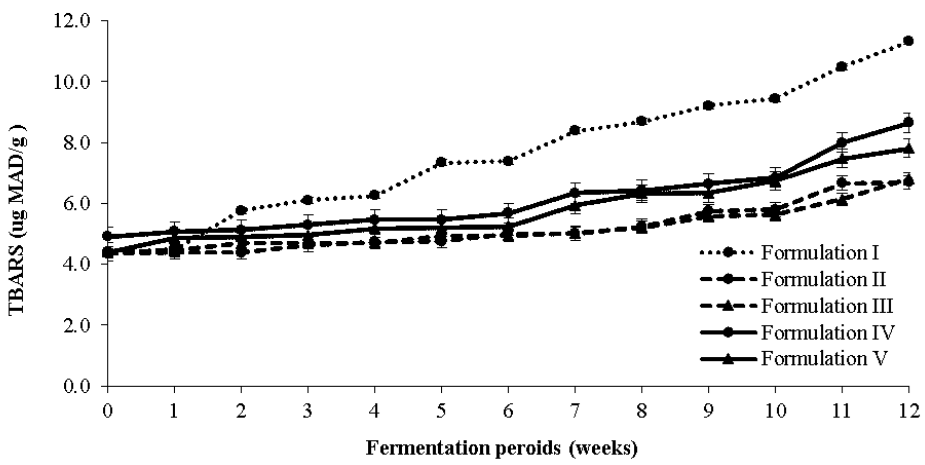

Figure 3 Changes in TBARS of fermented shrimp paste with partial replacement of sodium chloride during fermentation period. Formulation I: $100 \% \mathrm{NaCl}$ salt, formulation II: $\mathrm{NaCl}$ and $\mathrm{KCl}$ at $50 \%$ each, formulation III $\mathrm{NaCl} 75 \%$ and $\mathrm{KCl}$ at $25 \%$, formulation $\mathrm{IV} \mathrm{NaCl}$ and $\mathrm{CaCl}_{2}$ at $50 \%$ each and formulation $\mathrm{V} \mathrm{NaCl} 75 \%$ and $\mathrm{CaCl}_{2} 25 \%$

\section{Change in antioxidant activities}

Change in percentage of inhibition antioxidant activities of fermented shrimp paste during fermentation periods as analyzed by DPPH and ABTS radical scavenging activity are shown in Figure 4. The percentages of inhibition DPPH and ABTS radical scavenging activity were evaluated in fermented shrimp paste collected every week for 12 weeks. The results show that the percentage inhibition of DPPH and ABTS radical scavenging activity significantly increased $(\mathrm{P} \leq 0.05)$ with increasing fermentation period, however there was no significant difference between treatments (Figure 4). The increase of percentage inhibition in both DPPH and ABTS radical scavenging activity might be due to the active breakdown of protein to peptides and amino acids by the initial bacterial load in shrimp paste. Similar to previous studies reporting that peptides, amino acids and maillard reaction products in the fermented products possessed the antioxidan activity (Parelta, et al., 2008; Prapasuwannakul, Suwannahong and Saksri, 2014). This indicated that peptides or free amino acids in fermented products possessed the ability to donate the hydrogen atom to free radicals, in which the propagation process could be retarded.

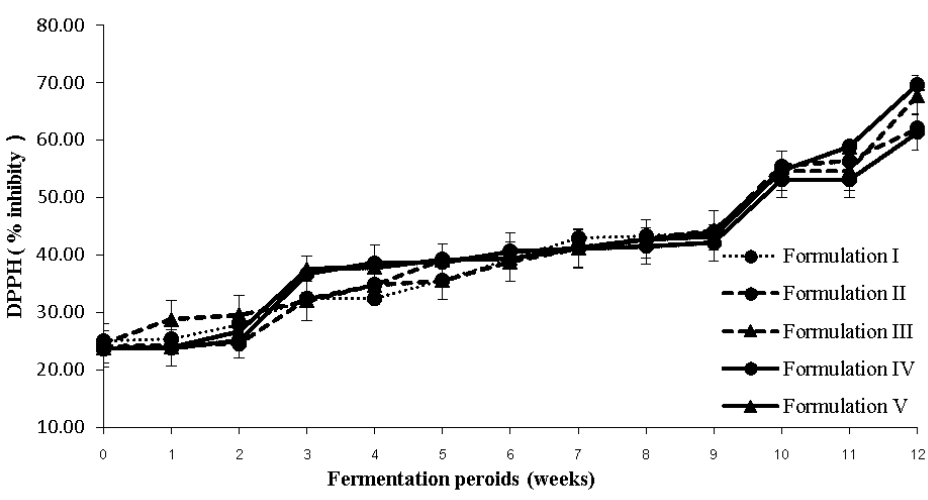

Figure 4 Changes in DPPH of fermented shrimp paste with partial replacement of sodium chloride during fermentation period. Formulation I: $100 \% \mathrm{NaCl}$ salt, formulation II: $\mathrm{NaCl}$ and $\mathrm{KCl}$ at $50 \%$ each, formulation III $\mathrm{NaCl} 75 \%$ and $\mathrm{KCl}$ at $25 \%$, formulation IV $\mathrm{NaCl}$ and $\mathrm{CaCl}_{2}$ at $50 \%$ each and formulation $\mathrm{V} \mathrm{NaCl} 75 \%$ and $\mathrm{CaCl}_{2} 25 \%$

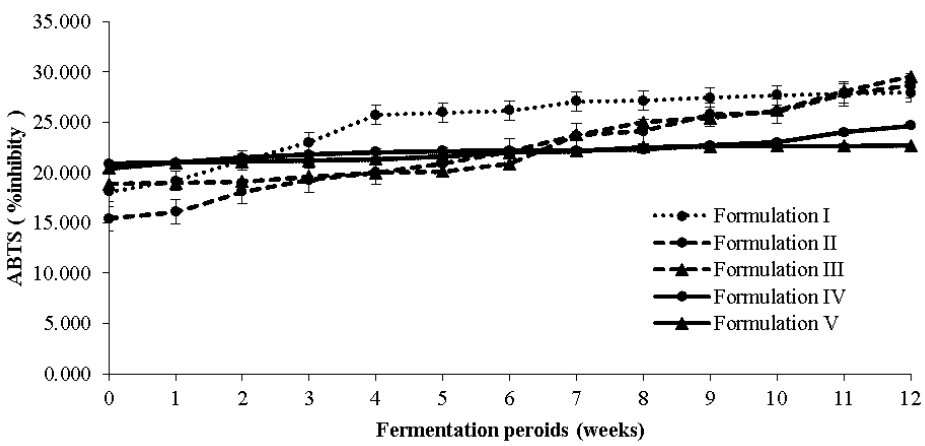

Figure 5 Changes in ABTS of fermented shrimp paste with partial replacemen of sodium chloride during fermentation period. Formulation I: $100 \% \mathrm{NaCl}$ salt, formulation II: $\mathrm{NaCl}$ and $\mathrm{KCl}$ at $50 \%$ each, formulation III $\mathrm{NaCl} 75 \%$ and $\mathrm{KCl}$ at $25 \%$, formulation IV NaCl and $\mathrm{CaCl}_{2}$ at $50 \%$ each and formulation $\mathrm{V} \mathrm{NaCl} 75 \%$ and $\mathrm{CaCl}_{2} 25 \%$

\section{Change in weight loss}

The weight loss tended to increase with the increasing fermentation period in every samples $(\mathrm{P} \leq 0.05)$. Weight loss in all samples were in the range $2.49 \pm 0.02$ to $2.77 \pm 0.05 \%$ (Figure 5). During fermentation, shrimp paste with $100 \% \mathrm{NaCl}$ (formulation I) had the highest weight loss compared to the other groups $(\mathrm{P} \leq 0.05)$. According to Sgarbiere (1998), this difference occurs because the addition of salt to meat products increases the ionic strength, improving the solubility and consequently the functionality of the myofibrillar proteins. Weight loss depend on many factors including temperature and relative humidity of ripening room, air movement and ripening time (Stebing and Roedel, 1987). 


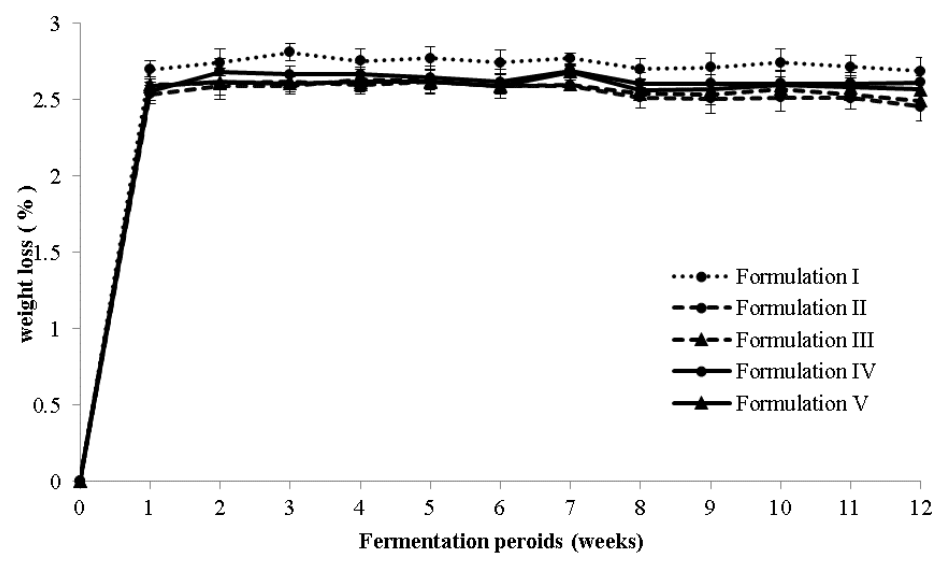

Figure 6 Changes in weight loss content of fermented shrimp paste with partial replacement of sodium chloride during fermentation period. Formulation I: $100 \%$ $\mathrm{NaCl}$ salt, formulation II: $\mathrm{NaCl}$ and $\mathrm{KCl}$ at $50 \%$ each, formulation $\mathrm{III} \mathrm{NaCl} 75 \%$ and $\mathrm{KCl}$ at $25 \%$, formulation IV $\mathrm{NaCl}$ and $\mathrm{CaCl}_{2}$ at $50 \%$ each and formulation $\mathrm{V}$ $\mathrm{NaCl} 75 \%$ and $\mathrm{CaCl}_{2} 25 \%$

\section{Change in color}

Color is the first quality attribute of food evaluated by consumers, and is therefore an important component of food quality relevant to market acceptance. The color of shrimp paste with partial replacement of $\mathrm{NaCl}$ during fermentation periods, obtaining $L^{*}, a^{*}$ and $b^{*}$ values are shown in table 1 .

Table 1 Changes in color of shrimps paste with the partial replacement of sodium chloride during fermentation periods

\begin{tabular}{lllcc}
\hline Formulation & $\begin{array}{l}\text { Fermentation time } \\
\text { (week) }\end{array}$ & $\boldsymbol{L}^{*}$ & $\boldsymbol{a}^{*}$ & $\boldsymbol{b}^{*}$ \\
\hline I & 0 & $39.59 \pm 0.06^{\mathrm{a}}$ & $7.09 \pm 0.08^{\mathrm{b}}$ & $7.81 \pm 0.05^{\mathrm{d}}$ \\
\cline { 2 - 5 } & 12 & $33.77 \pm 0.10^{\mathrm{cd}}$ & $9.39 \pm 0.04^{\mathrm{a}}$ & $12.03 \pm 0.02^{\mathrm{a}}$ \\
\hline II & 0 & $39.27 \pm 0.04^{\mathrm{a}}$ & $6.38 \pm 0.02^{\mathrm{c}}$ & $7.73 \pm 0.01^{\mathrm{d}}$ \\
\cline { 2 - 5 } & 12 & $34.09 \pm 0.03^{\mathrm{c}}$ & $8.93 \pm 0.10^{\mathrm{a}}$ & $10.15 \pm 0.12^{\mathrm{b}}$ \\
\hline III & 0 & $37.79 \pm 0.05^{\mathrm{a}}$ & $6.62 \pm 0.04^{\mathrm{c}}$ & $7.36 \pm 0.04^{\mathrm{d}}$ \\
\hline IV & 12 & $32.09 \pm 0.08^{\mathrm{d}}$ & $8.93 \pm 0.05^{\mathrm{a}}$ & $10.08 \pm 0.08^{\mathrm{b}}$ \\
\hline V & 0 & $40.36 \pm 0.04^{\mathrm{a}}$ & $4.68 \pm 0.08^{\mathrm{d}}$ & $6.58 \pm 0.06^{\mathrm{f}}$ \\
\hline & 12 & $31.72 \pm 0.07^{\mathrm{b}}$ & $7.89 \pm 0.07^{\mathrm{b}}$ & $9.39 \pm 0.03^{\mathrm{bc}}$ \\
\hline & 0 & $39.94 \pm 0.05^{\mathrm{a}}$ & $4.84 \pm 0.07^{\mathrm{d}}$ & $6.62 \pm 0.03^{\mathrm{f}}$ \\
\hline
\end{tabular}

Mean \pm SD from determinations.

Different superscripts in the same column indicate significant differences $(\mathrm{P} \leq 0.05)$

I, $100 \% \mathrm{NaCl}$; II, $\mathrm{NaCl} 75 \% \mathrm{KCl} 25 \%$; III, $\mathrm{NaCl} 50 \% \mathrm{KCl} 50 \%$; IV, $75 \% \mathrm{NaCl} 25 \mathrm{CaCl}_{2} ; \mathrm{V}, 50 \% \mathrm{NaCl} 50$ $\% \mathrm{CaCl}_{2}$

During fermentation, significance difference was found in every analyzed parameter as determined by the CIE Lab system. The $L^{*}$ values which were decreasing significantly that showing the lightness of the samples were from lighter to darker as fermentation progressed until 12 weeks $(\mathrm{P} \leq 0.05)$. The lightness of samples tested were ranged between $31.72 \pm 0.07$ and $40.36 \pm 0.04$ However, no significant difference was found in the samples with $\mathrm{KCl}$ replacement compared with formulation I $(100 \% \mathrm{NaCl})$. Agreement with Faithong and Benjakul (2012) studied the physicochemical properties of Kapi, a fermented shrimp paste, during fermentation, found that $L^{*}$ values decreased during fermentation period. On the other hand, $a^{*}$ values and $b^{*}$ values gradually increased with the increasing fermentation period $(\mathrm{P} \leq 0.05)$. The results indicated that the color of shrimps paste was developed extensively as fermentation period During extended fermentation, the autolysis might cause the increased release of carotenoids from carotenoprotein. Astaxanthin, protein-pigment complexes in shrimp, has a red-orange in color via denaturation of protein due to the separation of pigment from protein moiety (Schiedt et al., 1993).

$\underline{\text { Table } 2 \text { Acceptability score of fermented shrimp paste with the partial replacement of sodium chloride }}$

\begin{tabular}{lccccc}
\hline \multirow{2}{*}{ Formulation } & \multicolumn{5}{c}{ Attributes } \\
\cline { 2 - 6 } & Color & Flavor & Saltiness & Bitterness & Overall liking \\
\hline I & $8.57 \pm 0.25^{\mathrm{a}}$ & $8.60 \pm 0.36^{\mathrm{a}}$ & $8.00 \pm 0.02^{\mathrm{a}}$ & $8.41 \pm 0.15^{\mathrm{a}}$ & $8.52 \pm 0.02^{\mathrm{a}}$ \\
\hline II & $8.65 \pm 0.14^{\mathrm{a}}$ & $8.64 \pm 0.22^{\mathrm{a}}$ & $8.12 \pm 0.04^{\mathrm{a}}$ & $8.02 \pm 0.14^{\mathrm{a}}$ & $8.75 \pm 0.06^{\mathrm{a}}$ \\
\hline III & $8.35 \pm 0.17^{\mathrm{a}}$ & $8.65 \pm 0.14^{\mathrm{a}}$ & $8.09 \pm 0.08^{\mathrm{a}}$ & $8.00 \pm 0.11^{\mathrm{a}}$ & $8.42 \pm 0.08^{\mathrm{a}}$ \\
\hline IV & $6.53 \pm 0.09^{\mathrm{b}}$ & $6.86 \pm 0.28^{\mathrm{b}}$ & $6.67 \pm 0.15^{\mathrm{b}}$ & $6.73 \pm 0.09^{\mathrm{b}}$ & $6.53 \pm 0.07^{\mathrm{b}}$ \\
\hline V & $6.40 \pm 0.25^{\mathrm{b}}$ & $6.13 \pm 0.25^{\mathrm{b}}$ & $6.04 \pm 0.16^{\mathrm{b}}$ & $5.20 \pm 0.08^{\mathrm{c}}$ & $5.93 \pm 0.12^{\mathrm{c}}$ \\
\hline
\end{tabular}

\section{Means + SD from 25 determinations.}

I, $100 \% \mathrm{NaCl} ; \mathrm{II}, \mathrm{NaCl} 75 \% \mathrm{KCl} 25 \%$; III, $\mathrm{NaCl} 50 \% \mathrm{KCl} 50 \%$; IV, $75 \% \mathrm{NaCl} 25 \mathrm{CaCl}_{2} ; \mathrm{V}, 50 \% \mathrm{NaCl} 50 \% \mathrm{CaCl}$

Different superscripts in the same column indicate significant differences $(\mathrm{P} \leq 0.05)$

\section{Acceptability test}

The fermented shrimp paste were analyzed by an untrained 50-member panel. The results obtained for sensory evaluation for color, flavor, saltiness, bitterness and overall liking of samples with the partial replacement of $\mathrm{NaCl}$ are shown in Table 2. A significant higher scores in color, flavor, saltiness, bitterness and overall liking values $(\mathrm{P} \leq 0.05)$ in the samples obtained from 25 and $50 \mathrm{KCl}$ replacement (Formulation II and III) however there was no significant difference $(\mathrm{P} \geq 0.05)$ when compared with formulation $\mathrm{I}(100 \% \mathrm{NaCl})$. Jittrepotch et al. (2015) reported the replacement $\mathrm{NaCl}$ with 25 and $50 \% \mathrm{KCl}$ in fermented fish had the highest overall scores compared with the $\mathrm{CaCl}_{2}$ replacement, however, no significant difference from $100 \% \mathrm{NaCl}$. Askar et al. (1994) found out that the replacement is possible in these percentages without significant influence on the taste. At $60 \%$ of replacement by $\mathrm{KCl}$ the bitter taste in products is developed.

\section{CONCLUSION}

The results indicated that a reduction of $\mathrm{NaCl}$ by using $\mathrm{KCl}$ in fermented shrimp paste during fermentation period can be performed to develop healthier products with reduce $\mathrm{NaCl}$ contents. The reduction of $\mathrm{NaCl}$ by $\mathrm{KCl}$ in the fermented shrimp paste could be reduced lipid oxidation while decreasing the consumption of $\mathrm{NaCl}$. All samples possessed antioxidant activity, which could be an important source of natural antioxidants. Furthermore, replacement of 25 and $50 \% \mathrm{KCl}$ had the best sensory acceptance. Thus, from the point of view of the oxidative rancidity and antioxidant activities, we conclude that the addition of $\mathrm{KCl}$ is a good alternative to reduce $\mathrm{NaCl}$ content in fermented shrimp paste.

Acknowledgement: The present study was funded by Naresuan University (R2560B009).

\section{REFERENCE}

AOAC International. (2002). Official methods of analysis of AOAC International (17th ed.). Gaithersburg, MD: Association of Official Analytical Chemists. Askar, A., El-Samahy, S. K., Shehata, H. A., \& Tawfik, M. (1993). Pasterma and beef bouillon: The effect of substituting $\mathrm{KCl}$ and $\mathrm{K}$-lactate for sodium chloride. Fleischwirtschaft, 73(3), 321-324.

Buege, J. A., \& Aust, S. D. (1978). Microsomal lipid peroxidation. In Methods in enzymology (Vol. 52, pp. 302-310). http://dx.doi.org/10.1016/S0076$\underline{6879(78) 52032-6}$ 
Ellis, R., Gaddis, A. M., Currie, G. T., \& Thornton, F. E. (1970). Sodium chloride effect on autoxidation of the lard component of a gel. Journal of

Food Science, 35(1), 52-56. https://doi.org/10.1111/j.1365-2621.1970.tb12366.x Faithong, N., \& Benjakul, S. (2014). Changes in antioxidant activities and physicochemical properties of Kapi, a fermented shrimp paste, during fermentation. Journal of Food science and Technology, 51(10), 2463-2471. https://doi.org/10.1007/s13197-012-0762-4

Gusmoaõ̃O, T. A. S., Alexandre, A. M., Souza, N. G. G. D., Sassi, K. K. B. Gusmao, R. P. D., \& Moreira, R. T. (2017). Partial replacement of sodium chloride by potassium chloride in the formulation of French bread: effect on the physical, physicochemical and sensory parameters. Food Science and Technology, 37, 55-62. https://doi.org/10.1590/1678-457x.32216

He, F. J., \& MacGregor, G. A. (2009). A comprehensive review on salt and health and current experience of worldwide salt reduction programmes. Journa of human hypertension, 23(6), 363. https://doi.org/10.1038/jhh.2008.144

Jeong, J. H., Jung, H., Lee, S. R., Lee, H. J., Hwang, K. T., \& Kim, T. Y. (2010) Anti-oxidant, anti-proliferative and anti-inflammatory activities of the extracts from black raspberry fruits and wine. Food Chemistry, 123(2), 338-344 https://doi:org/10.1016/j.foodchem.2010.04.040

Jittrepotch, N., Rojsuntornkitti, K., \& Kongbangkerd, T. (2015). Physicochemical and sensory properties of Plaa-som, a Thai fermented fish product prepared by using low sodium chloride substitutes. International Food Research Journal, 22(2).

Kanner, J., \& Rosenthal, I. (1992). An assessment of lipid oxidation in foods (Technical Report). Pure and Applied Chemistry, 64(12), 1959-1964. https://doi.org/10.1351/pac199264121959

Meilgaard, M., Civille, G. V., \& Carr, B. T. (1990). Mutiple difference tests Balanced Incomplete Block (BIB) Designs. Sensory evaluation techniques, 105112.

Mizutani, T., Kimizuka, A., Ruddle, K., \& Ishige, N. (1992). Chemical components of fermented fish products. Journal of Food Composition and analysis, 5(2), 152-159. https://doi.org/10.1016/0889-1575(92)90031-e

Mora-Gallego, H., Guàrdia, M. D., Serra, X., Gou, P., \& Arnau, J. (2016) Sensory characterisation and consumer acceptability of potassium chloride and sunflower oil addition in small-caliber non-acid fermented sausages with a reduced content of sodium chloride and fat. Meat science, 112, 9-15. https://doi.org/10.1016/j.meatsci.2015.10.008

Nakao, Y., Konno, A., Taguchi, T., Tawada, T., Kasai, H., Toda, J. Terasaki, M. (1991). Curdlan: Properties and application to foods. Journal of Food Science, 56, 769-772. https://DOI: 10.1111/j.1365-2621.1991.tb05378.x

Nawar, W. W. (1996). Lipids. In O. R. Fennema (Ed.), Food Chemistry (pp. 225 314). New York: Marcel Dekker.

Peralta, E. M., Hatate, H., Kawabe, D., Kuwahara, R., Wakamatsu, S., Yuki, T., \& Murata, H. (2008). Improving antioxidant activity and nutritional components of Philippine salt-fermented shrimp paste through prolonged fermentation. Food Chemistry, 111(1), 72-77. https://doi.org/10.1016/j.foodchem.2008.03.042

Pengchumrus, W., \& Upanoi, T. (2005). Species and distribution of Acetes shrimps in seagrass beds and mangrove canals in the Andaman sea. Technical paper, (12).

Phithakpol, B. (1993). Fish fermentation technology in Thailand. Fish fermentation technology, 155-166.

Pongsetkul, J., Benjakul, S., Sampavapol, P., Osako, K., \& Faithong, N. (2015).

Chemical compositions, sensory and antioxidative properties of salted shrimp paste (Ka-pi) in Thailand. International Food Research Journal, 22(4), 1454

Prapasuwannakul, N., Suwannahong, K., \& Saksri, T. (2014). Effect of fermentation time on physicochemical properties and antioxidant activity of Klongkone fermented shrimp paste. Proceedings of the 1st Suan Sunandha National Conference on Ratanakosin Cultural Art for Thai community Development (pp. 233-240). Bangkok: Suan Sunandha Rajabhat University

Rajapakse, N., Mendis, E., Jung, W. K., Je, J. Y., \& Kim, S. K. (2005) Purification of a radical scavenging peptide from fermented mussel sauce and its antioxidant properties. Food Research International, 38(2), 175-182 https://doi.org/10.1016/j.foodres.2004.10.002

Rhee, K. S., \& Ziprin, Y. A. (2001). Pro-oxidative effects of $\mathrm{NaCl}$ in microbia growth-controlled and uncontrolled beef and chicken. Meat Science, 57(1), 105112. https://doi.org/10.1016/s0309-1740(00)00083-8

Sathivel, S., Bechtel, P. J., Babbitt, J., Smiley, S., Crapo, C., Reppond, K. D., \& Prinyawiwatkul, W. (2003). Biochemical and functional properties herring (Clupea harengus) byproduct hydrolysates. Journal of Food Science, 68(7), 2196-2200. https://doi.org/10.1111/j.1365-2621.2003.tb05746.x

Schiedt, K., Bischof, S., \& Glinz, E. (1993). [15] Metabolism of carotenoids and in Vivo racemization of (3S, $\left.3^{\prime} \mathrm{S}\right)$-Astaxanthin in the crustacean Penaeus. In Methods in enzymology (Vol. 214, pp. 148-168). Academic Press.

Sgarbieri, V. C. (1998). Propriedades funcionais de proteínas em alimentos Boletim da Sociedade Brasileira de Ciência e Tecnologia de Alimentos, 32(1), 105-126.

Steinkraus, K. H. (2002). Fermentations in world food processing. Comprehensive Reviews in Food Science and Food Safety, 1(1), 23-32 https://doi.org/10.1111/j.1541-4337.2002.tb00004.x
Stiebing, A., \& Roedel, W. (1987). Einfluss der relativen Luftfeuchtigkeit auf den Reifungsverlauf bei Rohwurst. Fleischwirtschaft, 67: 1020-1030.

World Health Organization. (2011). Review and updating of current WHO recommendations on salt/sodium and potassium consumption. Retrieved from http://www.who.int/nutrition/events/NUGAG dietandhealth subgroup call publ ic comment scope of $\mathrm{Na}$ K.pdf

World Health Organization. (2007). Reducing salt intake in populations: report of a WHO forum and technical meeting, 5-7 October 2006, Paris, France.

World Health Organization. (2014). Global Health Observatory (GHO), Raised Blood Pressure. Situations and trends. Retrieved from http://www. who $\mathrm{int} / \mathrm{gho} / \mathrm{ncd} / \mathrm{risk}$ _factors/blood_pressure_prevalence_text/en

Wu, H. C., Chen, H. M., \& Shiau, C. Y. (2003). Free amino acids and peptides as related to antioxidant properties in protein hydrolysates of mackerel (Scomber austriasicus). Food research international, 36(9-10), 949-957. 